\title{
THE ORGANIZATION OF THE MAJI MAJI REBELLION
}

\section{BY JOHN ILIFFE}

TH IS article ${ }^{1}$ analyses the limited documentation relating to the organization of the Maji Maji rebellion of $1905-7$ in the south and east of German East Africa. Perhaps a million people lived in the rebel area. The official guess was that 75,000 Africans died, mostly from famine and disease. An estimated 8,000 Pogoro and Mbunga assaulted Mahenge on 30 August 1905. Given these numbers, in an area without prior political unity, a crucial problem is to discover how the people were mobilized and organized for action. Three organizational principles require examination. First, the rebels may have organized according to prior political and cultural groupings, perhaps forming alliances between groups as often in past emergencies. Although the word has little meaning in the ethnic confusion of southern Tanzania, this method of organization may be called the 'tribal' principle. Second, the rebels may have utilized a sense of common grievance arising from the economic pressures of German rule. For reasons which must be explained, the economic status of some rebel peoples was moving towards that of a peasantry. The use of this common economic status may be called the peasant principle of organization. Third, an attempt to mobilize the southern peoples on a basis wider than the tribe might employ a religious principle of organization. It is probable that all three organizational principles were invoked at various times and places during the rising. As more evidence becomes available, a simple chronological sequence from one principle to another may become untenable, and any remaining pattern may be extremely complex, with wide regional variation. Yet, as a working hypothesis, it is perhaps worth while to set out a relatively simple pattern which is supported by much of the evidence now available.

It is therefore the thesis of this article that Maji Maji, as a mass movement, originated in peasant grievances, was then sanctified and extended by prophetic religion, and finally crumbled as crisis compelled reliance on fundamental loyalties to kin and tribe. Implicit in this thesis is the belief that the central historical problem of the rebellion is a corfflict, common perhaps to all mass movements, between the ideology of revolt and economic, political and cultural realities.

The sequence of organizational principles may be correlated with the geographical expansion of the movement. If the rebellion is dated from the death of its first victims, it began on the night of 31 July 1905 , in the Ma-

1 This article draws widely on the work of Professor T. O. Ranger, to whose generosity I am much indebted. The conclusions are naturally my own responsibility. 
tumbi Hills, and simultaneously (or even slightly earlier) in Madaba. From this nucleus, violence spread north to Uzaramo (before ${ }_{5}$ August), south to Liwale (somewhat earlier), and north-west to Kilosa, Morogoro, and Kisaki (by late August). This complex, centring on the middle and lower Rufiji, was the first unit of revolt. The second was the Lukuledi Valley, whither the rebellion expanded, via Liwale, during the last days of August.

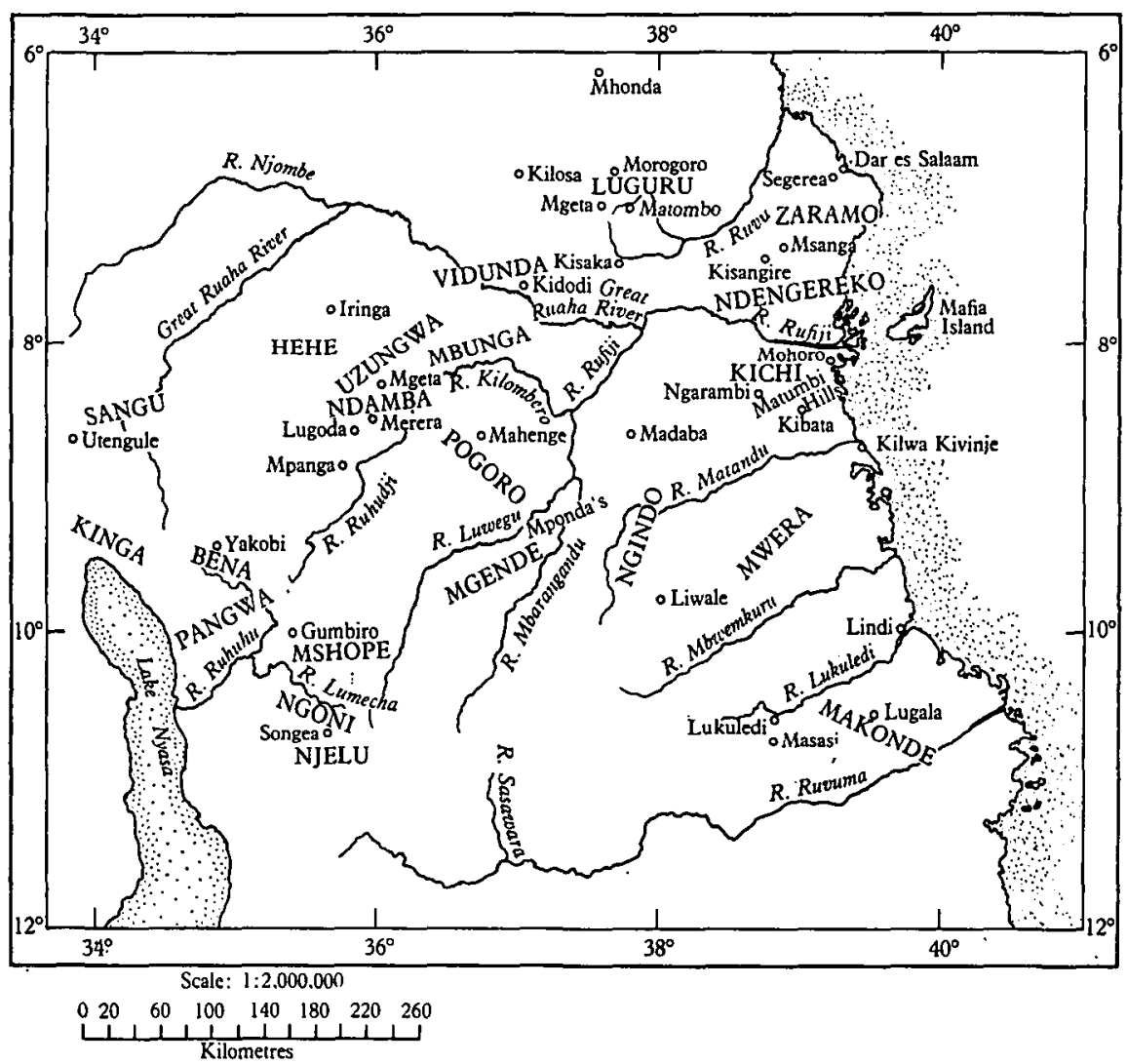

Fig. I

Simultaneously, the movement spread to the Kilombero Valley, the Mahenge Plateau, and Uzungwa, probably carried by the Ngindo and Pogoro. Finally, it was taken by the Ngindo to Ungoni early in September, whence it spread to Upangwa and southern Ubena. The Bena, who attacked Yakobi mission on 19 September, were the last to join.

It is useful to distinguish between the first area-the Rufiji complex-and the three other major areas of revolt. In the Rufiji complex, the rebellion began as a peasant movement. It expanded elsewhere through its acquired religious content. In the later areas, the tribal principle of organization quickly predominated. This article considers successively the peasant 
origins of the movement, the religious beliefs through which it spread, and its acceptance and transformation by the peoples outside the original nucleus.

An analysis of the origins of Maji Maji must explain why it happened in that particular area at that precise moment. It is sometimes argued that post-pacification revolts are in reality delayed resistances, initiated by decentralized groups unable either to offer effective resistance to the first European invasion or fully to comprehend its implications. Only after internal reorganization and experience of colonial rule, it is said, are such peoples convinced of their need and ability to resist. Maji Maji cannot be explained in this way. Several rebel peoples had previously offered quite severe resistance to the Germans. The Mbunga clashed with German forces several times between 1891 and 1893 . Many groups in the Kilwa hinterland had participated in Hassan bin Omari's resistance of r 894-95. The Makonde of the Lugala area, the only Makonde to rebel, had formed the core of the Yao warlord Machemba's followers, who had defied the Germans until I899. Again, although the Ngoni were more aware of the implications of colonial rule in 1905 than at first contact in 1897 , they were also in a less effective position to resist. ' 'Delayed resistance' is too simple a concept to explain the particularity of the rising. Nor can it easily be explained by general grievances against German rule-an explanation then common among left-wing groups in Germany. The imposition of taxation and brutal methods of collection, forced labour on road construction or European plantations, the replacement of indigenous leaders by alien agents (akidas) - all these were given as explanations. These were undoubtedly grievances, but they were shared widely in German East Africa, and were experienced much more profoundly elsewhere in the colony, especially in the north. More important, they were not new grievances in July 1905 , nor were they perhaps sufficiently burdensome to threaten the whole economy of the rebel peoples. If the initial stage of the rising is to be explained as a reaction to grievances, then the grievances must have been both more specific in time and place and also more destructive in their impact.

Such grievances existed in this particular area at precisely this moment. In 1902 a new governor decided to initiate large-scale African cotton-growing. Since cotton had failed on the northern coast, the experiment was confined to the south. Against much official advice, the governor doubted whether individual cultivation could be adequately supervised or produce worth-while results. He therefore ordered that a cotton plot be established in each neighbourhood of the experimental area, under the control of the local headman. Each of the headman's subjects would work for a fixed number of days on this communal plot. The Kommunalverband, the Euro-

* Ernst Nigmann, Geschichte der kaiserlichen Schutztruppe für Deutsch-Ostafrika (Berlin, 1909), 20-6r ; G. P. Mpangara, 'Songea Mbano', research seminar paper, University College, Dar es Salaam, Sept. 1966. 
pean-controlled district development committee, would supply seed and supervise cultivation and marketing. As originally planned, the headman, the workers, and the Kommunalverband would each receive one-third of the market price. ${ }^{3}$ The scheme began in Dar es Salaam district, whose administrator was the main advocate of 'communalization' and who introduced it to produce other cash crops and food before the plots were converted to cotton. The first plots were laid out in September and October 1902. The land was chosen by agricultural inspectors in consultation with the headmen. The normal plot was $2 \frac{1}{2}$ acres for each $30-50$ of the headman's adult male subjects. There were reckoned to be 25,000 of these in the district in I $902-3$, and some 2,000 acres were laid out in plots of between $2 \frac{1}{2}$ and 35 acres. The number of days to be worked is uncertain; twenty-eight per year, or two per month, were figures often quoted. No cotton was planted in 1902-3. The main crops were maize, millet, simsim, and rice. The total receipts were Rs. 19,185 . Headmen and workers received their portions in October 1903. Each headman received Rs. 35 and 46 pesa; each worker received 17 pesa. In $1903-4$ the plots were enlarged and the acreage estimated at 3,200 , of which 640 were devoted to cotton. The total proceeds

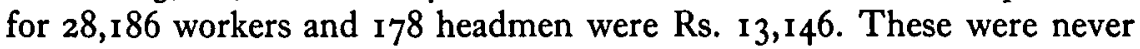
distributed. In the the third year only cotton was sown. This was expected to require $50-100 \%$ extra labour for the same acreage. And since cotton was more difficult to grow, control was tightened. The headman was made personally responsible for his plot, trainee agricultural assistants were sent to inspect, and a European official toured the whole area. ${ }^{4}$

The people of the Dar es Salaam district, the Zaramo, refused the 35 cents they were each offered for their first year's work. Refusal to work on the plots became fairly general during 1905 , and headmen either reported their loss of control or conscripted women and children as labourers. Headman Pazi Kitoweo of Msanga, interviewed in Dar es Salaam gaol, replied that his people 'would pay hut tax and also clear roads, but they would not work on communal plots'. The Commission of Enquiry into the causes of the rebellion in the district noted that the scheme had disrupted the family economy of the Zaramo, and, while providing 'a welcome bonus' for the headmen, had convinced the ordinary cultivator 'that government had devised a new means of obliging him to carry out a hated task for nothing'. ${ }^{5}$

Communal cultivation was introduced into Kilwa district (including Ungindo) in 1903 , when some 1,000 acres of cotton were laid out. On average the crop brought in Shs. 33/- per acre gross; the amount received by the workers is uncertain. The area was estimated at between 2,500 and 5,000 acres in 1904-5. European buyers offered between 4 and 7 cents a pound

3 'Gouvernementsrat beim Gouvernement von Deutsch-Ostafrika. Dritte Sitzung,' Dar es Salaam, 15/16 May 1905, Deutsches Zentralarchiv, Potsdam, Reichskolonialamt [RKA] 812/4I-58; Stuhlmann to Dernburg, and encl., 3 Oct. 1907, RKA 775/73-74.

4 Haber and Vincenti, 'Betr. Ursachen des Aufstandes im Bezirk Daressalam,' 7 Jan. 1906, RKA 726/109-25.

Ibid. 
before ginning. ${ }^{6}$ In Lindi district (south of the Mbwemkuru and east of the Sasawara), the scheme was inaugurated during the $1904-5$ season, when some I,950 acres were planted. None was picked. A fortnight after the outbreak of the rebellion, the district officer recalled his persistent opposition to the the scheme as 'inadvisable' and 'a restriction of native freedom'. During a recent tour, he had in effect promised that it would be abandoned. ${ }^{7}$ Of the other rebel districts, the scheme operated in Kilosa and Rufiji, but not, it appears, in Mahenge or Iringa. In Songea district, a settler organized sharecropping of cotton together with local headmen. In northern Uzaramo, where the scheme did operate, there was no rebellion. The programme was abandoned on the orders of the Colonial Secretary in February 1906.

The mere coincidence of time and place between cotton scheme and rebellion does not itself demonstrate that the former caused and delimited the latter. Yet the scheme probably was the major reason for the outbreak in the Rufiji complex in July and August 1905. It is worth summarizing the evidence which supports such a view. First, of course, although the cotton scheme was not in operation throughout the rebel area, the rising began where the scheme did operate. Second, it is surely significant that the revolt began early in the cotton picking season. Third, R. M. Bell's evidence suggests that the first outbreaks in Matumbi and Madaba were directly connected with orders to begin cotton picking. Fourth, several rebel leaders had suffered from the scheme. Of the Mwera and Matumbi leaders, Selemani Mamba, Chekenje, and Abdallah Kitambi appear on a list of headmen involved in the programme. Digalu Kibasila, the leader in Kisangire, was imprisoned during June 1905 for failing to require his people to cultivate cotton, and joined the rebellion almost immediately after release. $^{9}$ Fifth, cotton was everywhere an object of attack. In Kilosa the rebels burned the crop in the fields. 'The missionaries were hunted', reported the superior of the devastated Lukuledi mission, 'because they were Europeans and all Europeans are the same, all friends of taxes and cotton.' Mr Gwassa was told recently by Yusuf bin Issa: 'The origin of Maji Maji is cotton. Men and women were made to work together on government plantations contrary to accepted social practice and under the most harsh conditions. The natives of up-country resented this idea of forced labour even at the pain of war.' ${ }^{10}$ Although scarcely conclusive, this

- Haber to Götzen, 9 Sept. 1905, RKA 726/81-9o.

1 Ewerbeck to Government, 15 Sept. 1905, RKA 723/59-62.

8 Report by Albinus in Deutsches Kolonialblatt, I June I 905 ; Hohenlohe to Government, 17 Feb. 1906, RKA 726/68-76.

- R. M. Bell, 'The Maji-Maji rebellion in the Liwale district', Tanganyika Notes and Records, xxvuI (Jan. 1950), 39 ; list by Lergen, 28 Dec. 1904, Tanzania National Archives, Dar es Salaam [TNA] IV/G/2/I; Haber and Vincenti, 'Betr. Ursachen. .', I7 Jan. 1906, RKA 726/109-25.

10 Paul Fuchs, Wirtschaftliche Eisenbahn-Erkundungen im mittleren und nördlichen Deutsch-Ostafrikas (Berlin, 1907), 9; Thomas Spreiter, 'Bericht über die Zerstörung der Kath. Missionsstation Lukuledi', 9 Sept. 1905, RKA 723/43-47; G. C. K. Gwassa, 'A report on a research project in Kilwa district', typescript, Dar es Salaam, Aug. I 966. 
evidence does perhaps point to the cotton scheme as an explanation of the particularity of the outbreak. Yet the rebellion was not simply a protest against the introduction of commercial agriculture. Soon after the rising, to German surprise, cotton was widely grown by individuals in the Rufiji Valley. ${ }^{11}$ The protest had presumably been directed against obviously unacceptable methods of cultivation, against the consequent damage to the subsistence economy, and especially against the sheer unprofitability of the experiment.

Such grievances with the functioning of the commercial sector of the economy are the grievances of peasants. To speak of the peasant origins of the rising is not merely to give it a fashionable label, but is necessary if its changing character is to be understood, and if relevant comparisons are to be made. Maji Maji was not a 'peasant revolt', if this implies that it was wholly the action of peasants for peasant ends. Indeed, as Dr AlRoy has suggested, ${ }^{12}$ the concept of a peasant revolt as a distinct form of internal war is perhaps unfruitful. It is more useful to seek the degree and character of peasant involvement in the various stages of a mass movement. Peasant involvement predominated in the early stages of Maji Maji. Apart from the grievances specific to the outbreak area, there are two reasons for believing this. First any analysis of peasant involvement elsewhere suggests its amorphous, kaleidoscopic, essentially parochial character. The men of a locality hear that rebellion has broken out elsewhere. They congregate into a 'band', leaders and spokesmen emerge, the property of notable local enemies is destroyed and the enemies, if available, are killed. If they escape the area, they are rarely pursued. The band may coalesce with another and march jointly on a more prominent provincial centre, where the same process is repeated. Often the coalition dissolves and the men return home. Wider action is likely only if charismatic leadership has emerged, or if some millennial belief has been evoked. ${ }^{13}$ The early phases of Maji Maji seem to follow this kaleidoscopic pattern, although the impression of formlessness may derive chiefly from the inadequacy of the evidence. This planless, local character emerges clearly from Bell's account of events in Liwale and from Abdul Karim bin Jamaliddini's Utenzi wa Vita vya Maji-Maji. ${ }^{14}$ Having cleared their hills and sacked Samanga, the Matumbi returned to their homes, to mobilize again only when troops reached the area. The neighbouring Kichi dispersed once the headquarters of the local akidas were destroyed. Kimbasila's men remained in Kisangire, defying the government, but making no move beyond their homes. Such tactics clearly differed from the disciplined activity of the Ngoni, which will be described later. It is more diffi-

11 Grass to Government, 18 Jan. 1909, RKA 818I/215-24.

12 Gil Carl AlRoy, The Involvement of Peasants in Internal Wars (Center of International Studies, Princeton University, Research Monograph no. 24, I966), passim. I owe this reference to $\mathrm{Mr}$ J. S. Saul.

1s AlRoy, op. cit. pp. 35-6. See, for example, George Rudé, The Crowd in History, $1730-1848$ (New York, 1964), chs. I and 2.

14 Trans. W. H. Whiteley, Kampala, 1957. 
cult to decide whether this represents the difference between the actions of peasants and of tribesmen, or between those of ill-organized and of wellorganized tribesmen. To show that the former distinction holds, it is necessary to consider the second reason for believing that peasant involvement predominated in early rebel actions.

If, on one level, the great African rebellions against early colonial rule can be traced to administrative abuses, equal or greater abuses existed in other areas where only small-scale unrest occurred. To explain a rebellion the causes alone are insufficient; the organizational possibility must also be demonstrated. This is peculiarly difficult for Maji Maji. As Professor Ranger has shown, other movements of rebellion and resistance in East and Central Africa occurred amongst peoples - the Shona and Ndebele, Nandi, Kiga, Barwe-where a historical appeal was possible. ${ }^{15}$ It may prove that the Maji Maji rebels do have some historical unity, but this seems extremely unlikely. They lack even close linguistic affinity. ${ }^{16}$ It remains possible, of course, that they have a historic religious unity, conceivably based on a religious system established before the movements and coalescence which formed the recognizable rebel groups. Since the Ngindo-Mwera group are probably recent immigrants from the south, they may have moved into an area already under the religious authority of the Pogoro and Luguru. The Pogoro, at least, claim long settlement. This possibility is attractive, but there is at present no evidence whatever to support it, nor is there evidence in the rising of any historical appeal. An explanation of the possibility of organizing so widespread a movement must therefore concentrate on the then existing connexions among the rebels. The peoples within the Rufiji complex were distinguished from later rebels precisely by their closer approximation to peasant status. As normally defined, this has a dual meaning. First, peasants are rural producers whose surpluses are not devoted to 'equivalent and direct exchange of goods and services between one group and another; rather, goods and services are first furnished to a centre and only later redirected' ${ }^{17}$ Second, peasants possess a culture (perhaps a 'folk-culture') distinct from a literary, esoteric, and normally urban version of the same culture within the same economic and political unit. ${ }^{18}$ The peoples of the Rufiji complex approached this status through their long relationship with the East African coast. 'Their 'folk-culture'

$15 \mathrm{~T}$. O. Ranger, "The role of Ndebele and Shona religious authorities in the rebellions of 1896 and 1897 ', in Eric Stokes and Richard Brown (eds.), The Zambesian Past (Manchester, 1966), esp. 96 ; idem, 'Connections between "primary resistance" movements and modern mass nationalism in East and Central Africa', University of East Africa Social Science Conference Paper, Dec. 1966; idem, 'Revolt in Portuguese East Africa', in St Anthony's Papers, no. 15 (ed. K. Kirkwood, London, 1963), 54-80.

${ }_{10}$ Dr Bryan distinguishes between a Zaramo-Luguru-Vidunda group and the Ndengereko, Ngindo, and Mbunga languages. Kipogoro may either belong to a Hehe linguistic group or be considered separately. Kimatumbi, similarly, may belong to the Hehe or Ngindo groups. M. A. Bryan, The Bantu Languages of Africa (London, 1959), 123-36.

${ }_{17}$ Eric R. Wolf, Peasants (Englewood Cliffs, N.J., I 966), 3.

18 Robert Redfield, Peasant Society and Culture (Chicago, 1956), ch. 2. 
was distinct from the literary subculture of the coast, while their economy stood in an unequal relationship to the coastal trading area, recently supplemented by German political and economic authority. This relationship was demonstrably conscious and central to them-among the Zaramo, for example, the sense of situation between coast and 'interior' had found religious expression. ${ }^{19}$ The prestige of the coastal subculture probably aided the expansion of the rising inland. The high degree of mobility and intercommunication among the early rebels may have been possible only because of these shared economic and cultural circumstances.

If the origins and early character of the rising are to be found in peasant grievances and peasant action, its subsequent development falls more clearly into a general pattern. In recent papers, ${ }^{20}$ Professor Ranger has argued that several rebellions and resistance movements in East and Central Africa sought new methods of organizing effective mass action. Their integrating principles were often ideological, and the agents of reorganization were religious leaders. Further, since the object was to organize anew, it was not sufficient merely to revitalize structures and beliefs which often reflected those divisions which had previously hindered effective action. Rather, it was necessary to enlarge the scale both of resistance and of religious allegiance. The central figure in such an enlargement was the prophet, proclaiming a new religious order to supersede the old, a new loyalty to transcend old loyalties of tribe and kinship. German observers saw in Maji Maji the signs of such a transformation. The maji-the watermedicine accepted by each rebel-united in common action peoples with no known prior unity. Its power was believed to be religious, or in German terms was due to witchcraft. And it inspired its recipients with a passionate courage of which the Germans had believed their subjects incapable. An early analysis by the Chief Secretary, Eduard Haber, explained:

The leaders have attempted to work systematically on the broad mass of commonly indolent and apathetic natives through the use of so-called witchcraft... The stronghold of witchcraft seems to lie near Ngarambi on the Rufiji. There a family of witchdoctors trains subordinates. They receive water which, as they pass through the land, they sprinkle over the washenzi to make them immune to any mishap and to European weapons. Associated with the use of the water, it appears, is a revival [Wiederaufleben] of a cult of the snake-god Koleo among the Wazaramo and Waluguru.

The witchcraft was undoubtedly able to achieve such resounding success only because the broad mass of the natives believed they had grounds for profound dissatisfaction with the German administration. One may perhaps discern a reciprocal action [Wechselwirkung], in the sense that the natives, in their...

10 Martin Klamroth, 'Beiträge zum Verständnis der religiösen Vorstellungen der Saramo im Bezirk Daressalam (Deutsch-Ostafrika)', Zeitschrift für Kolonialsprachen, I (1910-11), r48-51.

20 Ranger, works cited, and 'African reaction and resistance to the imposition of colonial rule in East and Central Africa', in L. H. Gann and P. Duignan (eds.), History and Politics of Modern Imperialism in Africa (Stanford, forthcoming). 
bitterness against administrative demands, resorted of their own accord to the witchdoctors, while the leaders and fomenters of the rising skilfully used native discontent to effect their purposes. For the upheaval is too well planned to be the product of sudden decisions, while use of the water-witchcraft apparently cannot be traced before the middle of June this year. ${ }^{21}$

Thus Haber visualized the conjunction of two elements of equal importance: the grievances which brought the people to the ministers of the Kolelo cult, and the plans of these ministers utilizing popular distress. The common German view, however, detected a conspiracy imposed on the ignorant masses. This explanation originated with Moritz Merker, who commanded the reprisals in the Matumbi Hills. He believed that a group of chiefs and religious leaders secretly planned a revolt, distributing water as a panacea while insinuating that it would also give immunity. Large groups travelled openly to fetch the water from Ngarambi. 'The true incitement was to follow at the last moment before the outbreak of hostilities. These were to be started simultaneously by each of the committed chiefs at an agreed moment, which was to be a few months after the first of August. Fortunately... this did not happen, but they began in Kibata at the end of July, apparently owing to a private quarrel between two Matumbi headmen.'22 If Merker had evidence of prior planning, it does not survive. The conspiracy theory was later challenged by Bell, in whose account the initiative was taken by the Matumbi, who sought assistance from Kolelo's minister, Bokero, at Ngarambi, and returned to attack their akida. Farther west, according to Bell, the people of Madaba were given maji by Bokero's brother-in-law, Ngameya. At first they accepted it as a panacea, with fertility as its main element, but later visitors were told that it was effective against Europeans. When news of war reached Madaba, Ngameya was rumoured to be its leader, and he sent deputies (hongo) to distribute maji and direct operations. ${ }^{23}$

These accounts stress the role of the ministers of Kolelo. If the religious authorities who co-ordinated the Rhodesian risings of $1896-97$ had counterparts in Maji Maji, these are the most likely. Kolelo is first mentioned by Burton:

[The Luguru] have a place visited even by distant Wazaramo pilgrims. It is described as a cave where a P'hepo or the disembodied spirit of a man, in fact a ghost, produces a terrible subterraneous sound, called by the people Kurero or Bokero; it arises probably from the flow of water underground. In a pool in the cave women bathe for the blessing of issue, and men sacrifice sheep and goats to obtain fruitful seasons and success in war. ${ }^{24}$

1 Haber to Götzen, 9 Sept. rgo5, RKA 726/81-90.

"Moritz Merker, 'Uber die Aufstandsbewegung in Deutsch-Ostafrika', MilitärWochenblatt, xCI (1906), 1023-30.

93 Bell, loc. cit., passim. Hongo is a title of unknown origin and meaning. The identity of the many hongo active during the rebellion is an important topic for future research.

24 Richard F. Burton, The Lake Regions of Central Africa, (2 vols, New York, 196r) I, 88-9. See also A. R. W. Crosse-Upcott, 'The origin of the Majimaji revolt', Man, LX (1960), art. 98. 
A more detailed account is given by Martin Klamroth, an informed Lutheran missionary who served in Maneromango shortly before and after the rising. According to Klamroth, the Zaramo believed that the creator, Mungu, had sent Kolelo (a great snake) 'to restore order to all that is corrupted here on earth'. On arrival, Kolelo had taken to wife a woman of the Mlali clan, and ordered that 'your people of the Mlali clan shall be my people and serve me here forever in this cave in the Uluguru mountains'. Both Klamroth and recent accounts state that Kolelo was visited at regular intervals by his hereditary representatives (wazagila) from various parts of Uzaramo. On reaching the spot (known as Kolelo, near Matombo) the mzagila was taken to a place above a cave where Kolelo's words could be heard. The minister of the cult informed Kolelo of the mzagila's mission. In Klamroth's account, Kolelo brummt (boomed or grunted) unintelligibly, and the minister interpreted an order, which might, for example, be to return to Uzaramo and carry out certain rites. Klamroth suggests that the phenomenon was an underground waterfall. Other accounts state that any individual who followed the necessary observances might approach Kolelo. In particular, those accused of witchcraft were taken to be judged by Kolelo, or could appeal to Kolelo for judgement. ${ }^{25}$ Burton's statement that the spirit was called 'Bokero' suggests a link with the cult-centre at Ngarambi on the Rufiji, whose chief attendant, entitled Bokero, was believed by the Germans to have first distributed the maji. Others have confirmed that there is such a link, and that there are further cult-centres in the Rufiji area, although that in Uluguru remains the senior branch. The cult apparently flourishes, and people travel from many parts of southern and eastern Tanzania to seek medicines for rain and fertility. ${ }^{26}$

Three points emerge from these accounts. First, the Kolelo cult was influential over a wide area, and operated as German and other accounts of Maji Maji suggest. It provided centres to which large numbers of people went to receive medicine and instructions which they distributed on return. Second, the cult was chiefly concerned with the crops and the land. One of Klamroth's informants commented: 'If the crops prosper, the Zaramo do not think of Kolelo'. ${ }^{27}$ It is tempting to link the resurgence of the cult to German interference with the crops and the land. Third, the cult may have possessed specifically supernatural elements-mediumship, possession, and command over death. According to Hemedi bin Saidi:

Bokero was a demon [Shitwani]. He was not the name of a man. A man was possessed by the spirit Bokero [Ila mtu alikuwa alipagawa na pepo Bokera] and was simply used by Bokero. He was not a person, but the spirits [mizuka] which had entered a person. And indeed those Unbelievers believed him without understanding because he was like a god to them. ${ }^{28}$

85 Klamroth, loc. cit., I39-52; information from Miss J. Ritchie, Dar es Salaam, April 1966.

20 Information from Chief G. P. Kunambi, Dar es Salaam, July 1966, and others.

27 Klamroth, loc. cit., 146.

${ }_{28}$ Notes of an interview by Mr Gwassa, Kilwa Kivinje, July 1966. 
The evidence is perhaps sufficient to conclude that the Kolelo cult provided a machinery which could reach the peoples of the Rufiji complex. Yet there is no indication that it had political functions. It is curious and perhaps significant that the only area of Uluguru to join the rebellionMgeta-is on the opposite side of the mountains from Kolelo, and that for both the Luguru and Zaramo the source of medicine was the junior branch of the cult at Ngarambi. ${ }^{29}$ Nor do the accounts suggest that the cult had any role in warfare-until Maji Maji. Here the evidence is slight, and comes largely from Klamroth. It suggests that in the period before the rebellion the cult was transformed from its normal preoccupation with the land to a more radical and prophetic belief in a reversal of the existing order by direct divine intervention. Klamroth writes:

In the year 1905 ... Kolelo also concerned himself with politics. He (i.e. naturally the Zaramo who honour him) clearly decided that there were other needs to satisfy besides famine, and so the xenophobic movement of that year at first simply associated itself closely with Kolelo's name. Kolelo had forbidden the further payment of taxes to the white foreigners; in mid-July a great flood would come and destroy all whites and their followers. Later it was said that the earth would open and swallow them, that no bullets but only water would come from the soldiers' guns, seven lions would come and destroy the enemy, 'be not afraid, Kolelo spares his black children'.

Soon, however, other voices intervened. Now it was not Kolelo who looked after his children, but God himself, who had previously sent Kolelo. Kolelo, however, had not adequately fulfilled his task, so that God himself now appeared.

Clearly linked to this new situation was everything said at the time about the resurrection of the dead, since according to Zaramo conceptions only God himself, and not Kolelo, has unlimited power over life and death. It was later said that, before the rising, chief Kibasila of Kisangire, subsequently the main ringleader in Uzaramo, was won for their cause by the discontented spirits in the Matumbi Hills by a sham resurrection. He was said to have first become fully convinced of the rightness of the rebel cause when they showed him a man who had seen a remarkable likeness to his dead father. ${ }^{30}$

According to Klamroth, God was known as Kalava Dikono, which he translates as 'he has stretched forth his hand'. His prophets (mitumeKlamroth's translation) told Kibasila that they had seen his dead father. They promised that Kibasila might also see him if he offered 'the head of a white man, a European or an Arab'. ${ }^{31}$ According to Bell, Bokero had told Abdallah Mapanda precisely the same. A further account, headed simply Majimaji ao Kalava Dikono, bears out the general lines of this story. The prophets told Kibasila that they had been sent by his father to instruct him to defy the government in the name of the new god, who would come to live in the land: 'He will change this world and it will be new.... His rule will be one of marvels. When Kibasila replied that the government's

29 Klamroth, loc. cit., passim; Morogoro District Book (Area Office, Morogoro); Albert Prüsse, Zwanzig Fahre Ansiedler in Deutsch-Ostafrika (Stuttgart, 1929), 95.

so Klamroth, loc. cit., I40-1.

31 Klamroth, loc. cit., $141-3$. 
weapons were strong, the prophets sold him maji and told him to sell it for two pesa, secretly, and give the money to them for the mungu wa pesa mbili. Delighted, Kibasila did this and defied the government. The writer does not directly identify Kalava Dikono, and although at one point Kibasila's father shows himself by stretching out his hand from a swamp, at another point it is the god who does this. ${ }^{32}$

Where such confusion exists, little can be based on the evidence. Clearly, the Ngarambi branch of the cult was deeply involved in Maji Maji. Very probably its ministers were the first to distribute the maji, and certainly its commitment to the rebellion became clear during the first days of violence. It remains, however, to discover whether the ministers were planning a rebellion before violence began, whether they 'embodied and set the seal of ritual approval on the decision of the community as a whole', ${ }^{33}$ or whether they gave retrospective sanctification to violence already committed. On the present evidence, it seems more likely, as Haber first suggested, that there was a 'reciprocal action' between mass discontent and potentially prophetic leadership, their growing confidence in the maji impelling the people towards violence, and the increasing resolution of the people encouraging the religious leaders to expand their claims and objectives. The only indication of prior planning is that the maji was distributed for some weeks before violence began. Against this is the lack of evidence of any 'decision of the community as a whole', the very loose co-ordination of actions within the Rufiji complex, the complete absence of preparatory organization elsewhere, and the fact that the precipitant of violence in many areas was the unexpected news of war in the Matumbi Hills. Both Kibasila and Abdallah Mapanda, for example, received the maji and were told some of its powers before the rebellion began, but acted on it only after news of war arrived. The ministers of Kolelo had certainly taken a new initiative, but there is little sign that it was designed as an initiative for war.

To this point, the argument has concentrated on the first area of revolt, where the cotton scheme provided a new and critical grievance, economic and cultural circumstances offered the possibility of intercommunication, and where the cult of Kolelo held authority. Yet the rising rapidly expanded far beyond this nucleus, among tribes whose economic and political systems were relatively little affected by German rule, and where-to judge from the silence of the accounts-Kolelo's name carried less weight. Here the normal precipitant of violence was the arrival of a hongo from the east with news and maji. To understand the sequence of events which followed, it is important to stress that by no means all the peoples within the area of rebellion joined. Even among those who did, there were invariably groups which either remained passive or actively joined the German

32 Tuheri Abraham Beho, 'Majimaji ao Kalava Dikono', manuscript, Lutheran Mission, Maneromango, Nov. 1965. I owe this reference to Miss Ritchie. See also Ramadhani Mwaruka, Masimulizi fuu ya Uzaramo (London, 1965), 108-9.

s3 Ranger in Stokes and Brown, 96 
side. Some explanation of these different responses is suggested by analysing the actions of those peoples beyond the Rufiji complex for whom the evidence is most extensive. Those chosen are the Vidunda and Sangu, the Kibena-speaking peoples ruled by the Wakinamanga (Ubena of the Rivers), the Ndamba, the Mbeyela chiefdom in the south of highland Ubena, the Pangwa, and the Ngoni.

The factors which determined a decision to rebel are best illustrated by Fr. Schaegelen's account of the rising in Uvidunda. ${ }^{34}$ Maji Maji was brought to this area by a hongo whose identity is uncertain. He first approached a number of headmen and urged resistance. When they pointed to the power of European weapons, he sold them maji, with which he anointed them on face, chest, and legs. Although his claims and promises, as recorded, were remarkably similar to those made to Kibasila and others, three features of the Vidunda experience deserve special attention. First, the Vidunda understood the maji in the context of an attack on sorcery.

Hongo gave orders that every man must anoint himself with his Usinga medicine [i.e. the maji]; anyone who refused was to be caught and killed. People began to fear that they would be called witches and... went to Hongo to receive his medicine... No white magic or witchcraft was to be performed, no charms or medicines of any kind must be kept in their houses but all destroyed by fire.

Second, the movement was denounced by the Vidunda chief, Ngwira. The chieftainship was a relatively recent institution which had emerged from nineteenth-century defensive measures. Schaegelen writes:

All the Jumbes and old men went to Ngwira to tell him that a great witch-doctor Hongo had come to free them from the yoke of the Europeans... Ngwira was very angry when he heard these words for he realised that he was [an] impostor seeking to destroy the country... Hongo must be driven right away... But the Jumbes and old men paid no attention to his wise words.

With Ngwira discredited, 'Hongo appointed himself chief of the district. . . When Hongo saw that his strength was increasing... he gathered them together to go and take Kilosa.' The attack was a disaster. Several Vidunda were shot. 'Hongo had nothing to say.' Now began a third phase, the 'tribalization' of the movement in its later stages. 'After this they returned to their houses with their spoils. On arriving home they began to break the taboos of Hongo, they killed cattle, goats and sheep and brewed beer, for they knew that revenge was at hand.' At this point the hongo disappears from the story. Instead, the Vidunda turned to guerrilla warfare in their mountains, as so often in their history. Simultaneously, Ngwira's authority revived.

s4 Theobald Schaegelen, 'The ethnology of the Vidunda tribe', manuscript, 1945, in Kilosa District Book (Area Office, Kilosa). See also T. O. Beidelman, 'Notes on the Vidunda of eastern Tanganyika', Tanganyika Notes and Records, LXV (March 1966), 63-80. 
In recent years, social anthropologists have described a number of popular movements designed to eradicate sorcery ${ }^{35}$ from African societies. Dr Douglas has shown ${ }^{36}$ that among the Lele such periodic and shortlived movements are sharply opposed to routine measures to detect sorcerers and secure protection against them. Rather, they aim to rid the society of the possibility of sorcery by rendering its members unable either to practice or to suffer from it.

For the Lele [Dr Douglas writes] evil is not to be included in the total system of the world, but to be expunged without compromise. All evil is caused by sorcery. They can clearly visualize what reality would be like without sorcery and they continually strive to achieve it by eliminating sorcerers. A strong millennial tendency is implicit in the way of thinking of any people whose metaphysics push evil out of the world of reality. Among the Lele the millennial tendency bursts into flame in their recurrent anti-sorcery cults. When a new cult arrives it burns up for the time being the whole apparatus of their traditional religion...the latest anti-sorcery cult... is nothing less than an attempt to introduce the millennium at once. ${ }^{37}$

This analysis makes it conceivable that the Maji Maji rebellion, in its expansion beyond the borders of the Rufiji complex, was also a millenarian movement of this type. Schaegelen's narrative of events in Uvidunda supports such a description. Further evidence comes from the Mbeyela chiefdom of southern Ubena. Here, while the established cult of the ancestors, led by the chief, centred on Ukinga to the west, a series of antisorcery movements had entered from the east, from Ungindo and the Kilombero. Their apparent use of the mwavi ordeal may imply witchfinding rather than eradication, but Maji Maji was also brought by Ngindo, and it seems that the pattern of Bena response followed that normal with a mwavi medicine, the hongo administering the maji to the assembled people in the presence of the chief. ${ }^{38}$ Yet the most persuasive reason for linking Maji Maji with a millennial assault on sorcery is the evidence of subsequent eradication movements within the same area. The greatest, in 1926-29, were inspired by Ngoja bin Kimeta, a Ngindo who lived in Segerea village near Dar es Salaam. Partly through his own travels, and partly through his licensed agents, Ngoja's water medicines were administered to thousands of Africans from the coast to Ungoni and Kilosa. As with Maji Maji, the main nuclei were Ungindo and the Matumbi Hills, and expansion across tribal borders was astonishingly swift. There were close similarities in methods of distribution, in the response of tribal authorities, and in as-

ss I use this term to include also witchcraft. The primary sources do not permit a distinction.

so Mary Douglas, The Lele of the Kasai (London, 1963), ch. 13; idem, 'Techniques of sorcery control in Central Africa', in J. Middleton and E. H. Winter (eds.), Witchcraft and Sorcery in East Africa (London, 1963), 123-41.

37 Mary Douglas, Purity and Danger (London, 1966), 171.

sa Information from Mr M. S. Ndikwege, Dar es Salaam, July 1966. See also E. A. Mwenda, 'Historia na Maendeleo ya Ubena', Swahili, xxxi1, no. 2 (1963), 113-17. 
sociated beliefs. Ngoja was a respected Muslim, which accords with the undoubted participation of many Muslims in Maji Maji and the coastal prestige which seems to have aided the inland expansion of both movements. ${ }^{39}$ This is difficult evidence to evaluate. There is at present no indication of an eradication movement prior to $1905,{ }^{40}$ and Ngoja's activities may have been modelled on Maji Maji. Yet it seems very probable that both the rebellion and the subsequent movements were drawing on an established pattern of indigenous millenarianism. Just as the rising in the Rufiji complex became associated with the cult of Kolelo, so its expansion appears to have taken place within the context of recurrent movements to eradicate sorcery.

The second notable aspect of the Vidunda experience is the conflict between established political authority and prophetic leadership. Whether or not a people chose to rebel probably depended largely on this struggle for power. Established leaders responded in very different ways. Some, like Ngwira, opposed the movement and were swept aside. Others opposed the movement successfully. Yet others put themselves at its head and sought to control and direct it. For example, of all the peoples within the rebel area, the Sangu had the most powerful and successful political leadership. After long conflict with the Hehe, the Merere dynasty had welcomed and allied with the Germans and had won back its homeland. Then came Maji Maji. On two occasions, it appears, the Sangu decision lay in the balance. During September, Merere refused to receive a missionary, fortified his capital, and failed to send the auxiliary warriors demanded by the local German officer. Only the appearance of a military force brought him to the German side. Again, in late January, he seems to have been in contact with the Ngoni leader Chabruma. Missionaries reported a second crisis, but again a German force raced to Utengule, and Merere once more provided auxiliaries. It seems likely that a conflict took place within the Sangu leadership, and it is tempting to ascribe the subsequent decline of the dynasty to this. Merere IV died in 1906-allegedly from poison-and his successor was exiled to Mafia in 1910 for misgovernment. ${ }^{41} \mathrm{~A}$ comparable situation existed in lowland Ubena. Although most of his people were anxious to rebel, the powerful and pro-German Kiwanga dealt with the threat by rallying immediately to the German side. 'Kiwanga', reported a missionary, 'simply cut the throat of every medicine-man.' Less dramati-

so This account is based on T. O. Ranger, 'Witchcraft eradication movements in central and southern Tanzania and their connection with the Maji Maji rising', research seminar paper, University College, Dar es Salaam, Nov. 1966.

to The earliest Tanzanian example known to me occurred in Usambara in 1906 . See the correspondence in TNA IX/A/16/I.

"1 Kleist, 'Bericht über die Tätigkeit der 8 Feld-Kompagnie', 4 May 1906, RKA 700/232-41; report by Johannes in Deutsches Kolonialblatt, 15 Sept. 1906; Anlage A sum Fahresbericht über die Entwicklung der deutschen Schutzgebieten in Afrika und der Südsee im Fahre 1905/1906 (Berlin, 1907), 34; Ernst Nigmann, Die Wahehe (Berlin, I908), 6, I I ; Rechenberg to RKA, 7 Jan. 1911 , RKA 702/130-31; G. A. von Götzen, Deutsch-Ostafrika im Aufstand 1905-6 (Berlin, 1909), I 16-17, 212. 
cally, the chief's son and ultimate successor recalled how his father, rejecting the hongo's message, 'was ordered to follow this man Hongo who had deceived the people and the elders, and to turn the hearts of the people back from their faith in his medicine'. The hongo, however, 'refused to go before Kiwanga, and the elders who followed Hongo refused also. They would pretend to agree to follow Kiwanga, but they never meant it. They delayed and delayed and in the end never appeared. ${ }^{42}$ Early in October the Mbunga and Pogoro rebels in the area renewed their resistance by specifically attacking Kiwanga and Kalimoto, a loyalist Mbunga subchief, 'since they love the Germans more'. Kiwanga was eventually shot dead by the rebels. Here, as in Usangu, a disruption of the chiefdom followed the rebellion. ${ }^{4}$

Particularly clear evidence of conflict caused by the arrival of the maji is available for the obscure Ndamba people of the Kilombero Valley, whose political organization was weak and most of whom were subject to Kiwanga. The leading family in this area was headed by Undole, who lived in Merera. The hongo first brought water to the neighbouring Mgeta area. Undole sent an agent to investigate. Although the agent was persuaded, 'drank' the maji and returned full of enthusiasm, Undole summoned the elders of the neighbourhood and told them: 'I do not want to hear that my people in my country are drinking maji. Similarly, I do not wish to welcome these people with maji into my country. Majimaji is a false medicine brought by the Ngindo from Mponda's.' The elders departed, but the movement was too strong:

Even Mtwa Makuwa in Lugoda and Masalika in Mkaja tried to prevent their people from drinking the maji ya Hongohongo... [Nevertheless] the waganga wa maji deceived Masalika and caused him and his people to drink the maji ya uzima, although Undole had strongly opposed it. They moved on to Makuwa at Lugoda and there they employed the same methods as with Masalika. He also was given the maji, and he drank.

When Undole heard that the elders had joined the rebels, he summoned them. They came and listened, but his authority over them was slight. The elders returned to join the rising; Undole sent messengers to Mahenge, who fought alongside the Germans. Undole's people were spared, but the remainder of the Ndamba suffered the normal fate. ${ }^{44}$ Thus the pattern suggested by Schaegelen's account is supported by evidence from other areas. Maji Maji spread as a millenarian revolt which threatened established authority. Only the strongest could reject it.

12 Berliner Missionsgesellschaft report in Deutsches Kolonialblatt, I March 1906; Mtema Towegale Kiwanga in A.T. and G. M. Culwick, Ubena of the Rivers (London, 1935), 55 .

4. P. Aquilin Engelbergers Wapogoro-Tagebuch (ed. J. Henninger, Micro-Bibliotheca Anthropos no. 13, Freiburg, 1954), 387-427; Culwick, 90; Militärisches Orientierungsheft für Deutsch-Ostafrika (Daressalam, I $9 \mathrm{II}$ ), section 4.

1t Blasius Undole, 'Habari za Wandamba', typescript, $\mathrm{r}^{965}$ (copy in the present writer's possession). This account may be distorted by its family origin. 
The Vidunda evidence also describes a third phase, in which the failure of the maji obliged the rebels to return to customary methods of tribal warfare. This was one means by which the movement was tribalized in its later stages. Alternatively, a different process could take place. Dr Douglas has shown that movements to eradicate sorcery are able to adapt to local beliefs and circumstances until their original form is obscured. ${ }^{45}$ As Maji Maji expanded further south and west, it entered areas of strong political authority. In consequence, the revolutionary character of the movement declined while the element of tribal warfare grew. It has been seen that the Bena chief, Mbeyela, was willing and able to patronize and control the movement. ${ }^{46}$ Among the neighbouring Pangwa, whose chief also sided with the rebels, Maji Maji was not brought by alien hongo but by Pangwa resident in Ungoni. ${ }^{47}$ In the south-east, it appears, the movement operated from the beginning within a tribal framework. The most convincing evidence comes from Ungoni.

Zwangendaba's $\mathrm{Ngoni}^{48}$ had divided in the nineteenth century into northern and southern sections (Mshope and Njelu), although these united in crises, as during the Hehe wars of $1878-82$. After these wars fissiparation continued, especially in the more settled south, where nkosi Mputa was considered illegitimate by many ndunas, and where the great warrior Songea established a power rivalling Mputa's. The decision to accept the maji was taken in the north by nkosi Chabruma, perhaps under pressure from his ndunas, but in the south by the individual ndunas, some of whom, including Songea, took the maji before Mputa. During the first phase of rebellion, each unit operated independently. Owing perhaps to the lay character of Ngoni chieftainship, it appears that none of the Ngoni leaders saw the maji as a threat to his position, any more than their suecessors were to fear Ngoja's activities twenty years later. Yet many were sceptical. Songea is alleged to have said: "Let us "drink" the majimaji medicine so that we may all perish. ${ }^{49}$ Chabruma first consulted his diviners, and only then instructed his people to 'drink'. This suggests that the Ngoni did not see the maji as a revolutionary and self-legitimizing creed, although the Ngindo hongo commanded that all other medicines be burned. For Njelu, Mr Mpangara implies that the established war-diviner, Chikusi, was not consulted. There the hongo administered maji to a great assembly of warriors at the River Lumecha, presided over by Mputa and Chabruma. This

65 Douglas, The Lele, 245.

6 This point is made in M. J. Swartz, 'Continuities in the Bena political system', South-Western Yournal of Anthropology, xx (1964), 249.

4 Information from Fr. J. Stirnimann, Dar es Salaam, Nov. 1966.

48 This account is based on the following sources: Elzear Ebner, History of the Wangoni (mimeographed, Peramiho, 1959), 165-84; P. H. Gulliver, 'An administrative survey of the Ngoni and Ndendeuli of Songea district', typescript, 1954, Cory Papers, University College Library, Dar es Salaam; Mpangara, op. cit.; O. B. Mapunda, 'Nkosi Mputa Gama', research seminar paper, University College, Dar es Salaam, Sept. 1966; entry by O. Guise Williams in Songea District Book (Area Office, Songea).

"Mpangara, op. cit. 
assembly appears to have replaced the ceremony led by Chikusi which normally preceded Ngoni warfare. Apparently the Ngoni saw the maji not as a prophetic anti-sorcery medicine, as had the Vidunda, but as a new and uniquely powerful war medicine, superseding Chikusi's normal ministrations. This interpretation suggests the basically tribal nature of the Ngoni rebellion-perhaps more accurately described as a delayed resistancewhose organization and leadership drew on a functioning military system. What is significant about the impact of the maji is that during the Lumecha ceremony it provided a means for the reunification of the Ngoni people, whose last concerted action had taken place in $\mathbf{r} 882$.

Thus the paradox of later nationalist movements, the need to use old loyalties in order to popularize an effort to transcend them, also characterized this earlier attempt to enlarge political scale. The Maji Maji rebellion originated in peasant grievances, expanded through the dynamism of a millennial belief which challenged the old order, and finally came to reflect the cultural and political divisions of the past. Its changing organization demonstrates the tension within a mass movement between ideology and reality.

\section{SUMMARY}

This article examines the organization of the Maji Maji rebellion of $1905-7$ in German East Africa, utilizing Professor T. O. Ranger's analyses of other rebellions in East and Central Africa. The rising began in the Rufiji Valley as a peasant protest against a scheme, imposed by the German authorities, for communal cotton growing. But like other African rebellions against early colonial rule, the movement acquired an ideological content from prophetic religious leaders. This ideology enabled the rising to spread far beyond the Rufiji Valley and gave a degree of unity to diverse peoples. Two religious systems were involved. In the Rufiji Valley, the first rebels received a water-medicine from the ministers of the spirit Kolelo. This maji became the symbol of unity and commitment. The expansion of the movement beyond the nuclear area probably followed a pattern of recurrent millenarian movements whose chief object was to eradicate sorcery. Such a movement implied a challenge to established tribal authorities, and was seen by them as such a threat. As the rising spread, it entered areas of stronger tribal organization and also lost something of its revolutionary character. In consequence, the later rebels utilized tribal organization. This development, it is argued, conflicted with the original purpose of overcoming past political and cultural divisions in order to achieve more effective resistance to European rule. Thus, it is suggested, the rebellion demonstrated a tension between ideology and political and cultural reality which is characteristic of mass movements, including later nationalist movements. 